\title{
15 \\ WHO IS THE SELF IN INDIGENOUS SELF-DETERMINATION?
}

\author{
Sana Nakata
}

\section{Introduction}

In Australia, as in other settler colonial states, self-determination could not be practised as a process of decolonisation in which the coloniser exits the territory of the Indigenous sovereign. Rather, Indigenous selfdetermination in Australia from the 1970s to the turn of the twenty-first century was focused upon the transformation of an ongoing Indigenoussettler relationship, in which the settler state might be compelled or persuaded to transfer some decision-making powers to Aboriginal and Torres Strait Islander peoples. As other chapters in this book illustrate, these transfers took many forms with different effects in different parts of the continent. However, in this century, we have seen a rhetorical and substantive shift away from self-determination towards constitutional recognition - particularly since the 2010 establishment of the Expert Panel on Recognising Aboriginal and Torres Strait Islanders in the Constitution and through to the 2017 delivery of the Referendum Council report (inclusive of the Uluru Statement from the Heart). Constitutional recognition would be a structural reform, a pathway towards Indigenous justice in the context of ongoing colonisation. 
This chapter explores the history of the idea of self-determination in an effort to understand the difference between the discourse of selfdetermination and the discourse of constitutional recognition. While they are clearly related, I will argue that they place differentiated emphasis and demands upon processes of self-identification.

Self-identification has been an important element of self-determination, connecting the formation of individual identity to the collective assertion of nationhood. Internationally, policies that have enabled self-identification have enabled Indigenous nation-building and decolonisation. In the settler colonial context of Australia, however, self-determination has been associated not so much with nation-building and more with increasing Indigenous control of policy design, implementation and service provision; self-determination practised in this way has resulted in less than fully independent governance. As a result, the question of who is the 'self' in self-determination has been answered through the implementation of publicly verifiable criteria, through a three-part definition, allowing for clear delineation between those individuals to whom Indigenous policy applies and those to whom it does not. ${ }^{1}$ With the emergence of a politics of constitutional recognition, this delineation has become less important because specific material benefits are less immediately at stake in constitutional recognition discourses; thus the politics of constitutional recognition do not require the state or Indigenous communities and organisations to police Indigenous identities in the same way, or for the same purpose. Instead, constitutional recognition attends to the historical fact of colonisation as a foundation of the nation-state, and recognises the ongoing presence of First Australians generally, rather than through individual-level identification processes.

In being less prescriptive, this politics of recognition allows more complexity of historically emergent Indigeneities to be expressed by Aboriginal and Torres Strait Islander peoples. Any transfers of political power that might flow from such recognition are less immediately dependent upon the question: who is the self in Indigenous self-determination?

The chapter will first place Indigenous self-determination in its historical and local context. It will then consider the 'recognition' turn in political theory, and the academic debates this has produced with respect to Indigenous politics. In the third part, I engage with the ways Indigenous

1 See Gardiner-Garden, Defining Aboriginality. 
Australians describe their identity as a site of contestation through Bronwyn Carlson's book The Politics of Identity. My purpose is not to expand our understanding of 'who' the Indigenous self is in Indigenous self-determination; rather I seek to understand how the question of Indigenous identity became a site of both personal and political contestation. This contestation persists even as discourses of Indigenous claims to justice are shifting from the language of self-determination to constitutional recognition and beyond.

\section{Indigenous self-determination in historical context}

From the perspective of Western law and politics, self-determination can be considered a longstanding principle that relates the sovereignty of individual selves to the political legitimacy of state power. The principle of self-determination was evident in both the American Declaration of Independence (1776) and the French Declaration of the Rights of Man and Citizen (1791). In both, the consent of the governed underpinned the political legitimacy of the sovereign. As an organising principle of international relations on the European continent, self-determination can be dated back further, to at least the Peace of Westphalia in 1648. It was an expression of a much more longstanding commitment in Western moral and political philosophy: Autonomy. Freedom. Sovereignty. These are Western concepts that attach as much to individual human beings as they attach to nations and states. Thus, self-determination operates not only at the level of institutions and organised political communities but also at the level of autonomous individuals. Sovereign states are self-determining, but only because they are constituted of sovereign, individualised, selves. Discourses of self-determination then come to focus on the postcolonial formation of Indigenous individuals and their identity claims, not only on formations of self-determination in Indigenous institutions and governing bodies. Indeed, the normative value of these concepts of autonomy, freedom and sovereignty as they relate to individuals underpins the whole premise of a legitimate political order in the West: the people are sovereign, and the power of the state is legitimate only insofar as it commands the willing consent of the people. 
Asmi Wood, in his chapter for this book, has told how 'self-determination' acquired new significance in the twentieth century as the European and Ottoman empires came to an end and as norms of international conduct issued from first the League of Nations and later the United Nations. Selfdetermination is now a keystone in the new international order - present not only in the UN Charter, but also in the International Covenant on Civil and Political Rights and in the International Covenant on Economic, Social and Cultural Rights. In the Declaration on the Rights of Indigenous Peoples (UNDRIP), the General Assembly in 2007 attached Indigenous peoples' claims for justice to that principle. Australia endorsed UNDRIP in 2009 as a non-binding framework for better recognising and protecting the rights of Aboriginal and Torres Strait Islander Australians. As other chapters of this book show, the Australian Government began to label its approach to Indigenous affairs as 'self-determination' in 1973 a framework that guided policy on land rights, native title and Indigenous political rights, including on questions of representative structures and organisations. ${ }^{2}$

The 'idea' of self-determination can produce different forms of politics and political claim-making. Internationally, the discourse of Indigenous self-determination initially and primarily emerged as a framework for decolonisation following the vacating of colonised territories by diminished empires, in which the legitimacy of state claims to sovereignty is put under external examination. Domestically, in the context of ongoing settler colonial governance, self-determination has necessarily operated as a framework for Indigenous governance within a context of contested but near invincible state sovereignty. Internationally, the principle of self-determination allows the question: is the state's claim to sovereignty legitimate? Domestically, the principle of self-determination asks a different kind of question: what forms of policy and governance can legitimately be enacted over Indigenous peoples by the colonial state?

Dylan Lino helpfully expresses an important distinction in the literature on the right to self-determination between its external and internal aspects: 'the former generally being conceived of as the right of a people to be free from external domination, the latter as the right of a people to freely choose their political regime and to be autonomous. ${ }^{3}$ He describes the internal register as an 'appropriation' of self-determination, as a way

2 Lino, 'Towards', 840; Hunt, 'Between', 27.

3 Lino, 'The Politics', 846. 
Indigenous Australians have been able to 'frame' their political claims. ${ }^{4}$ The language of peoplehood - and its corollary, self-determination - is a language of international law, and this too has bolstered Indigenous demands. When the collective right of peoples to self-determination became prominent in the decolonisation era, Indigenous minorities in settler colonies were not seen to be among the right's beneficiaries (at least not independently of the settler states in which they resided). But especially from the 1970s onwards, Indigenous advocates globally, including in Australia, appropriated the linked ideas of peoplehood and self-determination to frame their political struggles. ${ }^{5}$

As a framework for decolonisation and as an appropriated framework for Indigenous people within settler colonies, self-determination operates to transfer power and resources from the coloniser to the colonised, giving rise to critical questions and challenges about policy, institutions and their governance. In both registers, self-determination operates as a practice or a mechanism to facilitate this transfer between political communities.

It is in this second 'internal' mode that self-determination has predominantly operated in Australia, superseding policies of 'protection' and 'assimilation' in which there had been 67 definitions, descriptions and classifications of Aboriginality written into over 700 pieces of legislation across the states and federal government to $1986 .{ }^{6}$ Just before the official inception of self-determination as a national policy in 1973, Section 127 of the Australian Constitution was deleted by the 1967 referendum so that the exclusion of Aboriginal and Torres Strait Islanders from Australia's total official population was no longer justified. This encouraged the Australian Bureau of Statistics (ABS) to publish national population totals that included Indigenous Australians. At the same time, the ABS sought to improve the accuracy of its counting by changing the census question so that it no longer asked respondents to differentiate themselves as 'full-bloods', 'half-castes' and 'quarter castes'. Official recognition that 'Aboriginal identity' was a social and not a biological construct was part of a wider shift in Australians' thinking of which the rise of the land rights movement in the 1960s and 1970s was another example. The land rights movement encouraged Aboriginal and Torres Strait Islander peoples to assert their diverse forms of social and political practice across

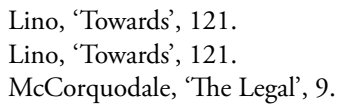


the continent in ways that have produced recognition of their humanity, their rights and their social and political identities. Another effect of the 1967 referendum was that it empowered the Australian Government to develop national policies, and this encouraged the Australian Government to produce a nationwide definition of 'Aboriginal' that conceded that Aboriginal identity was not determined by descent but by subjective identification and social recognition. The new three-part definition of 'Aboriginal' - formulated in 1968 and confirmed after a review in 1981 - was composed of (1) descent, (2) self-identification and (3) community recognition. ${ }^{7}$ This three-part definition was adopted by governments as a way to determine which Australians were eligible to benefit from targeted government programs, and it remains the dominant definition of Indigeneity in Australia today. ${ }^{8}$ A positive result from what is known as the Confirmation of Aboriginality process is recorded as an official written document in which an incorporated Aboriginal or Torres Strait Islander organisation endorses an individual's claim to Aboriginal or Islander identity; this is the operational form of 'community recognition'.'

Self-determination was a departure from assimilatory policies; it operated by developing legal and administrative devices to recognise and manage the 'Aboriginal domain'. ${ }^{10}$ This included changes to land title from the late 1960s onwards, and the statutory encoding of 'native title', as well as the creation of statutory bodies in the form of land councils that are ongoing. As well, self-determination included the (now defunct) Aboriginal and Torres Strait Islander Commission, and a range of other incorporated Indigenous bodies and organisations that deliver services to Indigenous peoples and communities, including forms of Indigenous local government that have superseded old missions and settlements. The proliferation of community-controlled health organisations, land councils, legal services and housing cooperatives indicates the transformative impact of selfdetermination in Australia. Nonetheless, the self-governing capacity of Indigenous communities has emerged without serious engagement with the complexities and multiplicities of Indigenous Australian's identity.

7 Department of Aboriginal Affairs, Report. For a description of the circumstances in which the Australian government reformed its definition, see Rowse and Smith, 'The Limits'.

8 See Gardiner-Garden, Defining Aboriginality.

9 Carlson, The Politics, 7.

10 Rowse, Remote. 


\section{The recognition turn - within and beyond self-determination}

To understand the similarities and the differences between the discourses of self-determination and of constitutional recognition we need to see how recognition is a requisite for justice. ${ }^{11}$ Recognition theory takes up a Hegelian master/slave dialectic to emphasise that identities are constructed in relational, rather than autonomous terms: constituted by a self-consciousness that allows us to understand who we are, in terms of who we are not. Identity is, in short, intersubjectively produced and takes shape especially in relation to our 'significant other'. Our significant others are those whose acts have a strong bearing on our sense of self. This might be immediate members of family and community, who may have positive or negative views of you. It is also those who hold positions of authority, and wield control, influence and power over us whether for good or for bad. As a site of justice, recognition produces an alignment between our sense of self and the sense with which our significant others understand us. As a site of injustice, non-recognition and mis-recognition risks the diminishment of self-esteem, self-respect and self-confidence in ways that do harm and violence to individuals and communities. ${ }^{12}$ Such accounts are compelling, but Indigenous political theorists Glen Coulthard and Audra Simpson remind us that not all slaves seek recognition of their master: Indigenous peoples are not necessarily looking to the settler colonial state to recognise or affirm our existence. On the contrary, Coulthard and Simpson remind us, in different ways, that, for many, justice lies in turning away from the coloniser's gaze, refusing the right of the coloniser to know us at all.

It is relevant to understand that issues of identity and recognition have been grappled with from within the self-determination discourse. For example, the 1986 report of UN Special Envoy Martinez Cobo identifies:

Indigenous communities, peoples and nations [as] ... those which, having a historical continuity with pre-invasion and pre-colonial societies that developed on their territories, consider themselves distinct from other sectors of the societies now prevailing in those territories. ${ }^{13}$

11 See Taylor, 'The Politics'; Honneth, The Struggle; cf. Coulthard, 'Subjects' and Red Skin; Simpson, Mohawk.

12 See Honneth, The Struggle.

13 Martinez Cobo cited in Daadaoui, 'The Western', 154. 
Daadaoui's social constructivist critique of Cobo highlights the disjuncture between two elements of this definition: the need for historical continuity in Indigenous identities and the need to acknowledge that colonisation has produced 'divergent self-perceptions and political discourses of groups and national societies, and diverse state-society relations'. ${ }^{14}$ The colonising process had the effect of dislocating Indigenous peoples from country; it reordered their social and family lives, and it deployed disciplinary practices that allowed the coloniser to know the colonised. Against this process, the requirement that Indigenous peoples must be able to assert pre-colonial identities, practices and knowledge systems against the colonial state as a condition for either self-determination or recognition is problematic.

In both self-determination and constitutional recognition, the importance of identity and the 'self' (individuated or collective) is easily displaced because it is so difficult to comprehend the multiplicities of being and subjectivities that produce Indigenous identity. Instead of grappling with the question of who is the self in Indigenous self-determination or of asking who seeks recognition from the Australian settler order, it is understandable that both the self-determination and constitutional recognition discourses must get on with the urgent and essential task of how we can develop mechanisms for the transfer of power from the settler order to Indigenous peoples, even if we cannot comprehend who those peoples are.

Both discourses maintain a focus on the transfer of power and resources, with attendant focus on issues of policy, governance and institutions, and both discourses continue to return to questions of identity. As Dylan Lino observes:

Australia's recent politics of Indigenous constitutional recognition can be seen as contests over Indigenous identity - over who Aboriginal and Torres Strait Islander peoples are - and what it means to respect that identity within the constitutional norms of the settler state. ${ }^{15}$

14 Daadaoui, 'The Western', 154.

15 Lino, 'Towards', 119. 
By the late twentieth century, Australian political discourse had shifted from a language of self-determination predominantly pursued through the domain of policy to one of 'constitutional recognition': for example, the 2012 report of the Expert Panel on Constitutional Recognition of Indigenous Australians, the 2014 Aboriginal and Torres Strait Islander Peoples Act of Recognition Review Panel, and the 2015 Parliamentary Joint Select Committee on Constitutional Recognition of Aboriginal and Torres Strait Islander Peoples. Most recently, the 2017 Referendum Council report has emphasised constitutional reform demanding deep structural change beyond mere symbolic recognition. ${ }^{16}$ This points to a shift to constitutional reform beyond the politics of recognition: constitutional reform demands the rewriting of the Australian Constitution not only to 'recognise' Aboriginal and Torres Strait Islander peoples but also to provide a constitutionally protected representative body that gives Aboriginal and Torres Strait Islander First Nations a Voice to Parliament, including the ability to monitor the use of the heads of power in Section 51 (xxvi) (the 'race' power) and Section 122. While recognition is a dimension of this proposed reform, and while matters of identification are relevant in understanding representativeness, questions of who the Indigenous self is are less acute than the question of who the Australian state is constituted for in the first place.

The discourse of constitutional recognition presents different terrain upon which we might make sense of the relation between identity and justice. Recent efforts to mobilise towards constitutional recognition are in some ways a response to the limits of self-determination. Glen Coulthard described in the Canadian context in 2007 that self-determination efforts and objectives ... have been increasingly cast in the language of "recognition". ${ }^{17}$ On the one hand, recognition can be understood as an effort to better capture the plurality of identities within and across groups and nations. On the other hand, as Coulthard makes clear, recognition offers up relational configurations between the coloniser and Indigenous peoples that risk reproducing rather than transcending historical oppression. ${ }^{18}$ If one is to turn towards recognition to take more seriously the constituting role of a sovereign self in claims for justice, then one will also find they are turned towards their coloniser (their master), their significant other, asking - indeed, begging - to be recognised.

16 See Davis and Langton, 'Introduction'.

17 Coulthard, 'Subjects', 437.

18 Coulthard, 'Subjects', 439. 
In Australia, this problematic politics of recognition played out in the efforts of the 'Recognise' campaign (2012-16), which sought to create a public movement in support for constitutional recognition of Australia's First Peoples. ${ }^{19}$ Megan Davis and Marcia Langton, in 2016, made clear that the gap between substantive reform desired by most Indigenous Australians and the public messaging required for a 'Yes' vote, 'explains why the ambiguity of the word recognition has led to a dissonance between the campaign to recognise and the Aboriginal political domain'.20 This dissonance was evident in two competing surveys on constitutional recognition in 2015: the first by Recognise suggested 87 per cent of Aboriginal and Torres Strait Islander peoples supported a symbolic form of constitutional recognition. Indigenous $X$ initiated its own survey and found support for this was much lower at 25 per cent. ${ }^{21}$ The Indigenous $X$ survey, which also returned more than 50 per cent support for an Indigenous parliamentary body being included in a referendum for constitutional change, highlighted the unwillingness of Aboriginal and Torres Strait Islanders to accept mere recognition of their ongoing presence in the Constitution and their insistence that substantive, structural reform of representation and political decisionmaking processes was necessary. Megan Davis also emphasises that there are many competing meanings of 'recognition' that are deployed in public conversation and debate about constitutional reform from the shallow and symbolic to substantive, structural reform. ${ }^{22}$ These competing meanings risk its operation as an 'empty signifier' in contexts in which precise details matter most. The relevance to this paper is to complicate assumptions surrounding a singular, unified, potentially essentialist understanding of Indigenous identities and political claim-making in discourses that are ever-preoccupied with the need to determine who the 'self' in Indigenous self-determination is, to determine who it is that seeks recognition from whom.

These two discourses can be usefully understood as having shared purpose: to remedy the injustice of dispossession and disempowerment enacted through historical and ongoing practices of colonisation. But this produces

19 Maddison, 'Recognise', 9.

20 Davis and Langton, 'Introduction', 5.

21 Celeste Liddle, ' $87 \%$ of Indigenous People Do Not Agree on Recognition. You'd Know if You Listened'. The Guardian, 19 June 2015, accessed 16 December 2019, www.theguardian.com/comment isfree/2015/jun/19/87-of-indigenous-people-do-not-agree-on-recognition-youd-know-if-you-listened. 22 Davis, 'Competing Notions'; see Davis, 'Correspondence'. 
a shared problem: the incomprehensibility of Aboriginal and Torres Strait Islander identity. ${ }^{23}$ In the discourse of Indigenous self-determination, the Indigenous 'self' has persistently sought expression and recognition within the Australian settler order, not only as individual human beings but also as a coherent collectively - a 'peoples'.

\section{Comprehending the politics of Indigenous identity in the settler colonial order}

For all that distinguishes self-determination from constitutional recognition, they are united by this shared purpose and shared problem. There is a historical continuity between the idea of self-determination (from the 1970s onwards) and efforts towards constitutional recognition (2006-16) and it is grounded in the incomprehensibility of Indigenous peoples within ongoing colonial contexts. In Australia, 'Aboriginal' is little more than the projection of a coloniser's taxonomy of the natural world. But the Aboriginal person has always been a real, embodied, human being - an individual nestled into family, kin, clan and nation - named by themselves, in their own languages, for their own needs. The 'Torres Strait Islander' is a specific invention of the Queensland legislature of 1939. Yet, here I am: both a fiction brought into being by the colonial order and also something else. This is the incomprehensibility of Aboriginal people. ${ }^{24}$ And it is to this incomprehensibility that I now turn.

In The Politics of Identity, Bronwyn Carlson expresses the deep plurality of Indigenous Australian identities and provides some insight into why the question of 'who' is so difficult in settler colonial contexts. She writes that, 'Aboriginal identity, whether we think of it in individual, local community or pan-Aboriginal terms, is a product of our position within and our relationship to the nation-state'. ${ }^{25}$ Here, she is not only

23 The turn toward recognition was partly a response to the limits of self-determination to engage seriously with the politics of identity alongside the politics of territory. However, constitutional recognition (and recognition theory more broadly) are also gravely limited in their capacity to comprehend Indigenous identities (Coulthard, 'Subjects of Empire'; Coulthard, Red Skin; Simpson, Mohawk Interruptus). This historical continuity of the incomprehensibility of Indigenous peoples suggests that what distinguishes self-determination from constitutional recognition may be less significant than sometimes suggested.

24 See Langton, Well; Langton, 'Aboriginal Art', 122.

25 Carlson, The Politics, 269. 
referring to colonial impact in its generic, all-encompassing sense, she is making quite specific reference to the three-part test for Confirmation of Aboriginality. ${ }^{26}$

This presents a central perversion of the principle of self-determination. The establishment of Aboriginal councils and community-controlled organisations is a key outcome of the self-determination effort in the early 1970s, allowing for the material transfer of some power and resources back to Indigenous Australian communities. Alongside this, the Racial Discrimination Act 1975 was crucial in making it illegal for Aboriginal and Torres Strait Islanders to be discriminated against, while still allowing for Aboriginal and Torres Strait Islanders to be positively discriminated towards in order to redress the inequitable distribution of resources and opportunities due to historical, structural and ongoing practices of colonisation. As with many things in Indigenous affairs, the perversion arises from 'good' intentions. If some people are to receive positive discrimination on account of their group identity, then it becomes necessary for those people to prove their membership to the group. However, it becomes incumbent upon Aboriginal communities and organisations themselves to act as the arbiters of Indigenous identity claims for reasons that have less to do with their own nationhood and more to do with the need to accommodate the settler order of things. As Carlson explains:

Any government, agency, employer, service or benefit provider which requires proof of Aboriginal identity to allocate a government benefit or service can accept a Confirmation of Aboriginality document from an individual only if it has been verified by an Aboriginal organisation, and only if that organisation has been formally incorporated under State or Territory legislation ... The Confirmation of Aboriginality is accepted as a pseudo-legal document by institutions and their officers, and demonstrates due diligence. ${ }^{27}$

The dislocation of people from their families, land, language and cultural practices is colonisation's defining characteristic wherever and whenever it occurs in the world. This means that supporting the self-determination of communities to provide them with the right to control and make decisions with respect to membership (producing and maintaining the

26 Carlson, The Politics, 7.

27 Carlson, The Politics, 133. 
self) also makes it exceptionally difficult for some Indigenous peoples to meet the three-part test (eliminating and diminishing the self). This is an uneasy tension from the perspective of self-determination. On the one hand, it is a form of self-determination. On the other hand, it is the devolvement of the very same colonial administrative regime that 'sorted' Aboriginal and Islander peoples for the purpose of implementing policies of family separation, education and employment to Aboriginal communities themselves. As Carlson concludes:

My study indicates that this wider picture [of the complexity of Indigenous identities] is a necessary one for us, the Aboriginal community, to understand how we are complicit agents of oppressive practices that restrict the creative regeneration and production of Aboriginal identities. ${ }^{28}$

Carlson persuasively sets out how this concern is not one of mere principle. The substantive contribution of her research is to detail the experiences of those Aboriginal people whose identity status might be ambiguous - whether due to family disconnection, or those of mixed heritage who may or may not be recognisably Aboriginal - with respect to the Confirmation of Aboriginality process. That some speak positively, and others negatively, is less significant than the way in which the process operates to keep 'colonial binaries alive', not only in terms of the significance of being able to distinguish between Indigenous and nonIndigenous peoples within the settler colonial context, but also in terms of a colonial binary between the power of the 'identifier' and the 'identified'. ${ }^{29}$ The binary here refers to the power relation between the institution who 'knows' and the individual who must be 'known'. That is, here it becomes evident that the question of who is the self in Indigenous selfdetermination is not the only question we should be asking. The other question is: how do the politics of identity come to be contested in the pursuit of the Indigenous 'self'? What power relations between institutions and individuals are taking place to sustain self-determination as a practice for Indigenous governance? And what are the effects of these relations on those subject to those power relations? This is not about the tension produced towards individual identity and selfhood and the legitimacy of collective Indigenous authority: the individual self and the self as a collective 'peoples' will always sit in relation to one another, sometimes

28 Carlson, The Politics, 269.

29 Carlson, The Politics, 122. 
easily and sometimes uneasily. What is of core concern from a perspective of law and politics is to understand how the 'self' - individual or collective - is transformed from an embodied, lived expression to a politically strategic manoeuvre necessary for ontological existence.

Whether the people she talks to have always known or only recently discovered their Aboriginal heritage, Carlson is able to describe diverse experiences and ways that people make sense of their Indigenous selves. In the cases of those who have always known, there is a sense that 'recognition' through Confirmation of Aboriginality is disconnected from one's actual identity:

It's not just about that piece of paper. I think to be Aboriginal you need to identify with a group of people. Actually, that could be really hard to identify too because you don't know that family. ${ }^{30}$

For some, it does not necessarily mean connection to community:

I think it means acknowledging ... my ancestry and just knowing who I am in that respect. Not necessarily being what I am doing or where I live ... not necessarily being part of community involvement and all that stuff. ${ }^{31}$

For others, it does:

[Aboriginality] means basically belonging to here and family. I guess association to the land and culture as well as knowing where I come from ... It's the search of wanting to know that deep meaning of where they've come from. ${ }^{32}$

So I am endeavouring to get connection back with culture. I was brought up in a white society, a white culture and I probably relate more to white society than Aboriginal society. But yeah, I feel there is an imbalance now, and I want to get a balance in my life with my Aboriginal side of the family. ${ }^{33}$

While for another, 'a part of that Diaspora of almost lost and forgotten Aboriginal Australians', the effect of colonisation means that his identity cannot be connected to land or community:

30 P10 [anonymised interviewee] quoted in Carlson, The Politics, 183.

31 P1 [anonymised interviewee] quoted in Carlson, The Politics, 186.

32 P7 [anonymised interviewee] quoted in Carlson, The Politics, 189.

33 P16 [anonymised interviewee] quoted in Carlson, The Politics, 193. 
I live in a world in which I don't belong in the sense that I was born in Leichhardt [suburb of Sydney] which is in Gadigal country but I have no connection to Gadigal people [apart from growing up there]. ${ }^{34}$

But for some, this is part of the injustice that defines Aboriginal identity:

Aboriginal people have had it hard and that is what makes us Aboriginal in some way, we all know about our past and what it means to be Aboriginal. So that is why, when people aren't really Aboriginal because they haven't faced these things, it isn't right they can say they are Aboriginal. ${ }^{35}$

In this context, it is unsurprising that Carlson's research showed that many Aboriginal people spoke about the 'gaps in their knowledge about what it means to be Aboriginal'. ${ }^{36}$ Thus, for many this means seeking out opportunities to learn and perform their identity, all the while having diverse experiences of how to do so:

I'm at a loss at the moment. I just find it really hard to find culture and I want to learn language. ${ }^{37}$

To my knowledge being Aboriginal was what I was taught at school as a whitefella. They lived in the bush a long time ago, wore loin cloths and speared roos and that was my understanding of being Aboriginal. So I was lost and just had no idea of who I was after that. ${ }^{38}$

I've changed the way I talk and everything ... I don't know ... have to be on the same level as people in the community so I don't look upper-class or I don't look like or I don't identify. ${ }^{39}$

We are still in limbo, don't know which world to fit in... I don't know when I should start saying 'cuz' or 'bruz', yeah, I don't know when I should start acting Aboriginal. ${ }^{40}$

34 P13 [anonymised interviewee] quoted in Carlson, The Politics, 192.

35 P23 [anonymised interviewee] quoted in Carlson, The Politics, 190.

36 Carlson, The Politics, 226.

37 P10 [anonymised interviewee] quoted in Carlson, The Politics, 230.

38 P8 [anonymised interviewee] quoted in Carlson, The Politics, 231.

39 P10 [anonymised interviewee] quoted in Carlson, The Politics, 236.

40 P10 [anonymised interviewee] quoted in Carlson, The Politics, 247. 
I labour these personal expressions of Aboriginal identities here to demonstrate the diverse experiences that Indigenous Australians have in comprehending, or making sense, of the 'self' in the modern settler colonial context. What comes through so strongly in Carlson's work is that this process of comprehension takes place at a 'cultural interface'. ${ }^{41}$ She writes that:

There was evidence in the transcripts of the interviews of the pushpull of the discourses of Aboriginality. A push against them as they operated to exclude some subjectivities, and the pull of them for the newly identifying trying to enter into the world of Aboriginal meaning or those wanting to belong and work as a member of the collective community. ${ }^{42}$

What Carlson exposes through these diverse experiences is the manner in which Indigenous Australian communities themselves have taken on the surveillance required for the settler colonial order to determine which persons count as Aboriginal today. ${ }^{43}$ Carlson's task is not to resolve these tensions but to:

Suggest there is room for Aboriginal people [as individuals] to reflect on and examine our own practices and our compliance with a de facto government regime that insists on applying definitional criteria for access to government resources as the complete 'truth' of what it also means to be Aboriginal in all aspects of our daily lives. ${ }^{44}$

\section{Conclusion}

In this chapter I have attempted to place the recommendations of the 2017 Referendum Council, which call for constitutional and structural reform, in a historical and theoretical context. The proposed reforms offer a move beyond 'the politics of identity' in Indigenous affairs potentially displacing the question of 'who' is the Indigenous self in Indigenous selfdetermination with a new question: how can the Australian state be made to hear the many voices of Aboriginal and Torres Strait Islander people on the issues that affect them? The determination of who is and who is

41 See Nakata Disciplining; Carlson, The Politics, 239-50.

42 Carlson, The Politics, 239.

43 Carlson, The Politics, 273.

44 Carlson, The Politics, 273. 
not an Aboriginal or Torres Strait Islander person should and could never become redundant. But the question of who we are, as individuals and collectives, ought to be reclaimed as a question for our many selves, as we navigate the complexities of being First Nations in a settler colonial order. The question of our identity needs no longer be a question for the state's organisation of our lives. Who is the 'self' in Indigenous selfdetermination matters less than understanding how and why and under what conditions that 'self' must be produced.

This is an effort to present a problematisation: an effort to reframe the ways in which we seek to understand who Indigenous Australians are and instead to focus upon why we ask for Indigenous expressions of self and sovereignty in the ways that we do. The final lines of Carlson's book ask:

In what other ways can we express ourselves and conduct a community discourse that is open to all Aboriginal experiences? What can we achieve in our relations with the wider nation-state if we are not so preoccupied in our community with regulating and surveilling each other for a few crumbs thrown under the master's table? ${ }^{45}$

My argument is a simple one: the question of who is the self in selfdetermination is a question that reveals the ways in which the politics of Indigenous identity helps to organise the settler colonial state's organisation of our lives, families and justice claims. In self-determination, the politics of our identities must produce a coherent and organised social and political community as a basis for our justice claims. In constitutional recognition, particularly in its symbolic form, our justice claims are predicated upon receiving recognition of the very master whose authority we refuse. In both, the politics of identity deepen our entanglements with the state in ways that risk deepening tensions within and between our many, diverse, 'Indigenous' selves. Problematising this is an effort to find space outside of the discourses that bind us.

The self in Indigenous self-determination is an idea: both a colonial idea and a colonising idea. A necessary fiction, and also a real body: educatable, incarcerable, governable. The self in Indigenous self-determination is also an ideal: that something past can be recovered, and that something new will be made. Having grappled with the history of self-determination, and as we turn towards future debate about deep, structural, constitutional 
reform, the answer to the question who is the self in Indigenous self-determination ought to begin to matter far less than an answer to the question: will Australia finally hear our many voices?

\section{References}

Carlson, Bronwyn. The Politics of Identity: Who Counts as Aboriginal Today? Canberra: Aboriginal Studies Press, 2016.

Coulthard, Glen S. 'Subjects of Empire: Indigenous Peoples and the "Politics of Recognition" in Canada'. Contemporary Political Theory 6, no. 4 (2007): 437-60.

Coulthard, Glen Sean. Red Skin, White Masks: Rejecting the Colonial Politics of Recognition. Minneapolis: University of Minnesota Press, 2014.

Daadaoui, Mohamed. 'The Western Sahara Conflict: Towards a Constructivist Approach to Self-determination'. Journal of North African Studies 13, no. 2 (2008): 143-56.

Davis, Megan. 'Competing Notions of Constitutional "Recognition": Truth and Justice or Living "Off the Crumbs That Fall Off the White Australian Tables"?' Papers on Parliament, no. 62. Department of the Senate, Parliament of Australia. October 2014. Accessed 6 January 2020. www.aph.gov.au/ About_Parliament/Senate/Powers_practice_n_procedures/ / / /link.aspx?_ id=4B5E02CC60064C6080B5ECBCACB5533D\&_z=z.

Davis, Megan. 'Correspondence: The Status Quo Ain't Working'. Quarterly Essay 70 (2018): 81-91.

Davis, M. and Langton, M. 'Introduction'. In It's Our Country: Indigenous Arguments for Meaningful Constitutional Recognition and Reform, edited by M. Davis and M. Langton, 10-34. Melbourne: Melbourne University Press, 2016.

Department of Aboriginal Affairs. Report on a Review of the Administration of the Working Definition of Aboriginal and Torres Strait Islander. Canberra: Commonwealth of Australia, 1981.

Gardiner-Garden, John. Defining Aboriginality in Australia. Current Issues Brief, no. 10 2002-2003. Canberra: Australian Parliamentary Library, 2002.

Honneth, Axel. The Struggle for Recognition: The Moral Grammar of Social Conflicts. Cambridge, MA: The MIT Press, 1992. 
Hunt, Janet. 'Between a Rock and a Hard Place: Self-determination, Mainstreaming and Indigenous Community Governance'. In Contested Governance: Culture, Power and Institutions in Indigenous Australia, edited by J. Hunt, D. E. Smith, S. Garling and W. Sanders, 27-54, Canberra: ANU E Press, 2008.

Langton, Marcia. 'Aboriginal Art and Film: The Politics of Representation'. In Blacklines: Contemporary Critical Writings by Indigenous Australians, edited by Michele Grossman, 109-24. Carlton, Vic.: Melbourne University Press, 2003.

Langton, Marcia. Well, I Heard It on the Radio and I Saw It on the Television... Sydney: Australian Film Commission, 1993.

Lino, Dylan. 'The Politics of Inclusion: The Right of Self-determination, Statutory Bills of Rights and Indigenous People'. Melbourne University Law Review 34, no. 3 (2010): 839-69.

Lino, Dylan. 'Towards Indigenous-Settler Federalism'. Public Law Review 28, no. 2 (2017): 118-37.

Maddison, Sarah. 'Recognise What? The Limitations of Settler Colonial Constitutional Reform'. Australian Journal of Political Studies 52, no. 1 (2017): 3-18.

McCorquodale, John. 'The Legal Classification of Race in Australia'. Aboriginal History 10, no. 1/2 (1986): 7-24.

Nakata, Martin. Disciplining the Savages: Savaging the Disciplines. Canberra: Aboriginal Studies Press, 2007.

Rowse, Tim. Remote Possibilities: The Aboriginal Domain and Administrative Imagination. Darwin: North Australia Research Unit, The Australian National University, 1992.

Rowse, T. and L. Smith. 'The Limits of "Elimination" in the Politics of Population'. Australian Historical Studies 41, no. 1 (March 2010): 90-106.

Simpson, Audra. Mohawk Interruptus: Political Life across the Borders of Settler States. Durham: Duke University Press, 2014.

Taylor, Charles. 'The Politics of Recognition'. In Multiculturalism: Examining the Politics of Recognition, edited by Amy Gutmann, 25-73. Princeton, NJ: Princeton University Press, 1994. 
This text is taken from Indigenous Self-Determination in Australia: Histories and Historiography, edited by Laura Rademaker and Tim Rowse, published 2020 by ANU Press, The Australian National University, Canberra, Australia.

doi.org/10.22459/ISA.2020.15 